\title{
IMPACT OF DEMOGRAPHIC TRANSITION ON KEY VARIABLES OF DEVELOPMENT IN KARNATAKA
}

\author{
Shruthi M. B. ${ }^{1}$ and Asima Nusruth ${ }^{2}$ \\ ${ }^{1}$ Research Scholar and ${ }^{2}$ Professor, \\ Manasagangothri, Mysore, India \\ Email: shru.appi15@gmail.com,Email:n_asima@yahoo.com
}

\begin{abstract}
One of the demographically developed states of the country Karnataka has already entered into the third stage of demographic transition which has its strong impact over the economic development of the region. The paper attempts trace the pattern of population change as well as to analyse the impact of demographic transition on economic development of various physiographic divisions of the state. A Partial Correlation model is estimated with the published data on Decadal Population Growth Rate (PGR), Life Expectancy (LE), Literacy Rate (LR), Work Participation Rate (WPR) and Net District Income (NDI). Finally the study reveals that the improved socio-economic conditions of the region will lead to the replacement level of demography.
\end{abstract}

Key words: Demographic Transition, Development, Birth rate and Death rate.

\section{Introduction}

Demographic transition is naturally based on the demographic experiences which have moved from a situation of high fertility and high mortality resulting slow growth of population to a situation of low mortality and low fertility which once again to a slow growth of population due to the socio-economic development of the region. Similarly, owing to the better socio-economic conditions of the state Karnataka also entered into the third stage of demographic transition slowing the population growth. But this transition is varied among the various physiographic regions of the state which also influences the different variables of development. Hence, the present study attempts to examine the relationship of demographic change with the variables of development.

\section{Objectives}

- To analyse the trends of population in different physiographic regions of the state.

- To examine the impact of demographic transition on the key variables of development.

\section{Methodology}

To show the Demographic transition level of the various physiographic divisions, the study uses C.P. Blacker's Five Stages of Population Growth Model where the population transition is classified into five stages such as High Stationary, Early Expansion, Late Expansion, Low Stationary and Declining Population stages. Impact of demographic transition on the key variables of development has been explored in the context of Karnataka for the period 19812011. The present study is based on secondary data obtained from Census of India Website, Directorate of Economics and Statistics and Karnataka State Gazetteer. Civil Registration System (CRS) on vital events are used to compute birth and death rates. A Partial Correlation model is adopted to estimate the impact of demographic transition on different variable of Development using SPSS.25.

\section{Study Area}

Karnataka is located on the western part of the Deccan plateau. The latitudinal extends of the state is between $11^{\circ} 31^{\prime}$ and $18^{\circ} 45^{\prime}$ North which forms $750 \mathrm{kms}$. of distance whereas longitudinally extends from $74^{\circ} 12^{\prime}$ to $78^{\circ} 40^{\prime}$ East which is about $400 \mathrm{kms}$. The total Geographical area of the state is about 191,791 sq. kiss. The state has geographically divided into four major divisions (Learmonth, A.T.A., op. cit.) based on homogeneity criteria like rain fall, climate, type of the soil, topography and so on. They are: 
1. Coastal Region

2. Malnad

3. The Northern Maidan and

4. The Southern Maidan

For the present study, the entire state has classified as four major divisions and some alternation for the delineation of physiographical division has done in accordance with the district boundaries as the age-specific census data are available at district level only.

Figure 01: Study Area

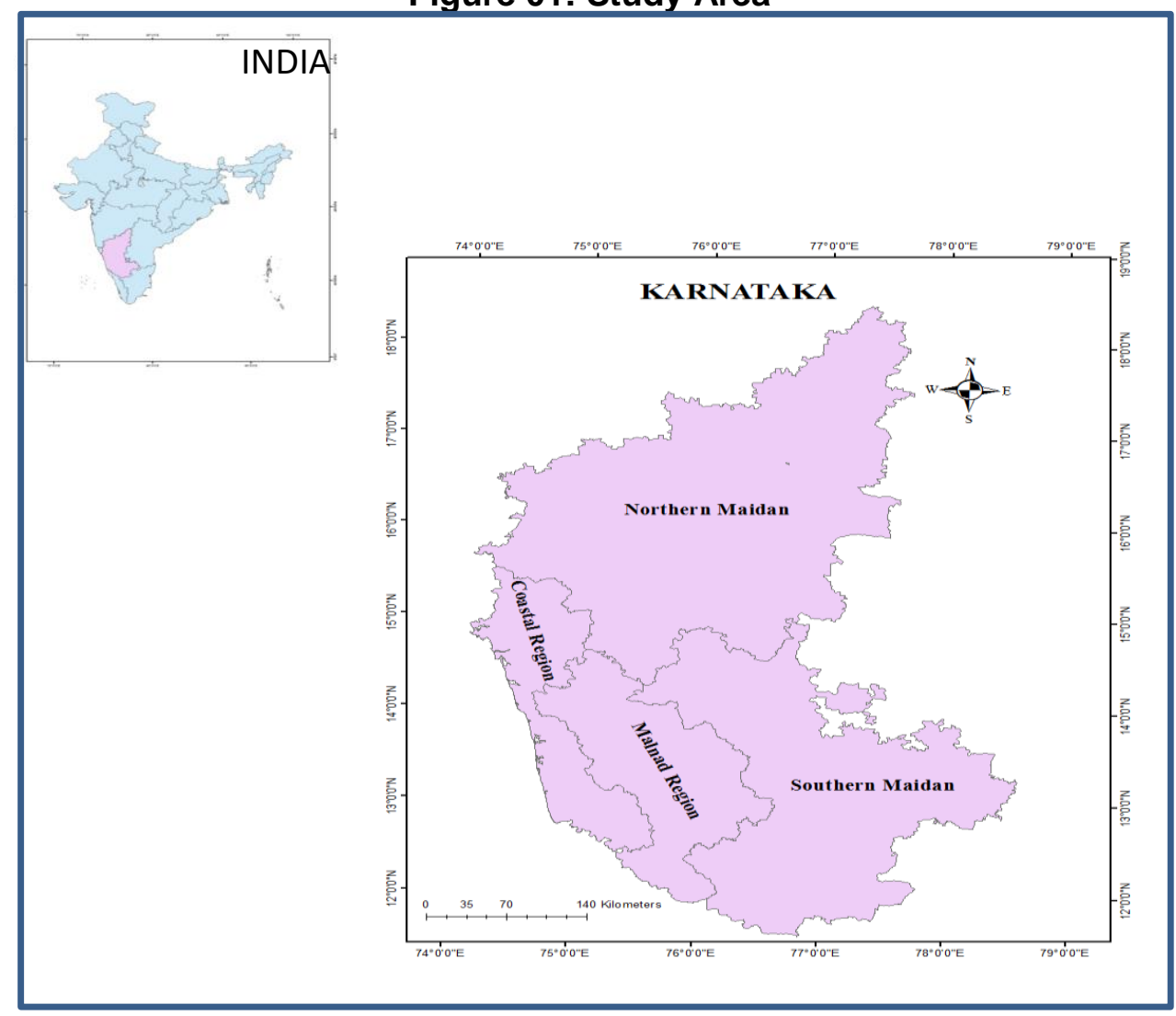

\section{Population Trends in Karnataka}

Population growth in the state to a large extent corresponds with the trend of population growth of the country (Ranganatha. 2012). Figure 2 shows that there was a slow growth of population either small or negative between the years 1901 and 1921, from 1931 trend takes a boost as well as experience steady growth up to 1961 whereas the duration between 1961 and 1981 shows rapid population growth in which 1981 records highest growth rate in the state. Due to the improved medical facilities and awareness regarding family planning population growth has been declining from 1991 till 2011.

Figure 02: Decadal Population Growth from 1901 to 2011

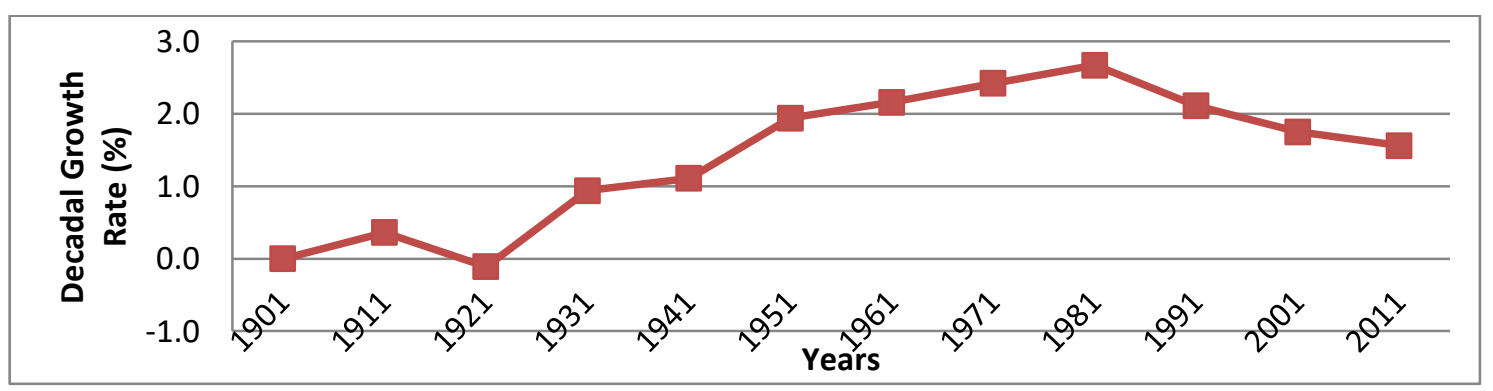

\section{Regional Variation in Population trends}

Various regions of the Karnataka experiences different growth rates which can be clearly observed in the figure 3. Most part of the Southern Maidan falls under Old Mysore provinces before State's Re-Organisation (1956) shows highest population growth more or less similar to the state's growth owing to the improved socio-economic conditions. Malnad region shows 
negative trend in 1911-21 due to the natural hazards like famine and epidemic diseases like plague, malaria, cholera, influenza and such other factors and it takes slight positive development in the following years, in addition to this there is a phenomenal ascend of $4.03 \%$ in 1961 owing to the eradication of malaria and control of other diseases, development of agricultural, industries and trade and so on (District Gazetteer, Shimoga. 1975) which later takes declining trend up to 2011. Coastal region and Northern Maidan shows almost similar pattern from 1931 to 1981 , there after coastal region experiences steady declining rate than the Northern Maidan.

Figure 03: Region Wise Decadal Population Growth from 1901 to 2011

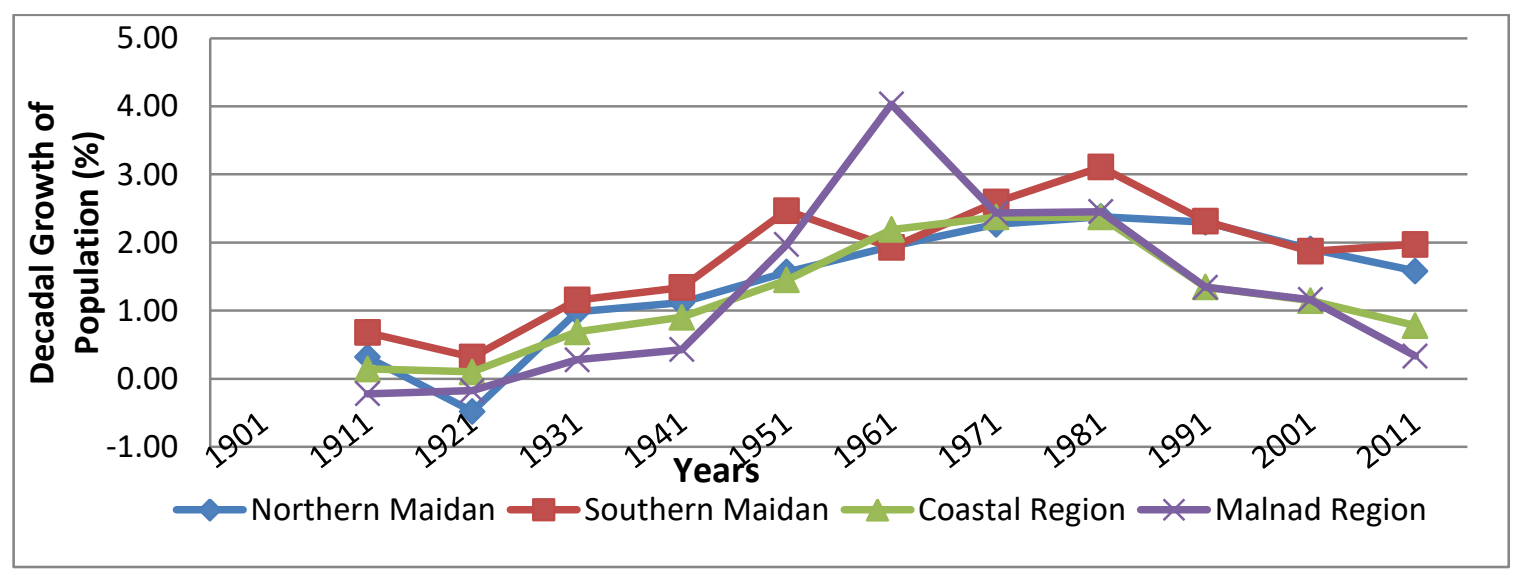

\section{Birth and Death Rate}

Though Demographic transition based on historical data, simplicity of its structure enables a sensible analysis of Birth and Death rates in a population (P. K. Majumdar. 2010). The study uses registered number of live births and deaths from 1971 to 2016 to reveal the scenarios of natural growth of population. Table 1 shows the decadal trends of birth and death rates per 1000 population in which except Malnad all the regions shows decreasing trend during period of 1971-81 in birth and death rate because of the awareness regarding family planning, improved medical facilities and decreased number of deaths due to the control of hazardous and epidemic diseases. But the rate has taken boost during 1991-01 and began to decline during 2011 as well as in 2016.

Table 01: Decadal Trends of Birth and Death Rate Per 1000 Population

\begin{tabular}{|c|c|c|c|c|c|c|c|c|c|c|c|c|}
\hline \multirow{2}{*}{ Regions } & \multicolumn{5}{|c|}{ Birth Rate (CSR) } & \multicolumn{5}{c|}{ Death Rate (CSR) } \\
\cline { 2 - 13 } & $\mathbf{1 9 7 1}$ & $\mathbf{1 9 8 1}$ & $\mathbf{1 9 9 1}$ & $\mathbf{2 0 0 1}$ & $\mathbf{2 0 1 1}$ & $\mathbf{2 0 1 6}$ & $\mathbf{1 9 7 1}$ & $\mathbf{1 9 8 1}$ & $\mathbf{1 9 9 1}$ & $\mathbf{2 0 0 1}$ & $\mathbf{2 0 1 1}$ & $\mathbf{2 0 1 6}$ \\
\hline $\begin{array}{c}\text { Northern } \\
\text { Maidan }\end{array}$ & 18.82 & 12.83 & 18.27 & 20.20 & 21.94 & 19.94 & 7.99 & 4.44 & 5.55 & 7.01 & 6.35 & 5.98 \\
\hline $\begin{array}{c}\text { Southern } \\
\text { Maidan }\end{array}$ & 13.53 & 11.72 & 16.96 & 17.62 & 15.00 & 13.77 & 4.64 & 3.95 & 5.31 & 6.65 & 5.95 & 6.35 \\
\hline $\begin{array}{c}\text { Coastal } \\
\text { Region }\end{array}$ & 21.63 & 17.47 & 20.49 & 22.50 & 18.00 & 17.48 & 6.22 & 3.87 & 5.87 & 8.03 & 7.87 & 7.51 \\
\hline $\begin{array}{c}\text { Malnad } \\
\text { Region }\end{array}$ & 10.01 & 10.57 & 15.34 & 19.58 & 16.41 & 15.48 & 3.49 & 3.24 & 4.24 & 6.65 & 6.43 & 6.91 \\
\hline
\end{tabular}

Source: 1. Office of the Chief Registrar of Births \& Deaths and Directorate of Economics \& Statistics Karnataka Bangalore. 2. Birth and Death rates are compiled by the authors

In Figure 4 Two Period Moving Average trend line has used to show the stages of population transition along with the Birth and Death rate. Southern Maidan attaining the replacement level of population growth very early compared to the other regions due to the improved socio-economic conditions of the region. Malnad and Coastal region are also maintains little gaps between the birth and death rates indicating the achievement of 'Low Stationary' level in following years. But Northern Maidan still experiencing slow declining trend over birth and death rate and will take many more years to accomplish the transition level. 
Figure 04: Region Wise Trends of Birth and Death Rates Growth from 1971 to 2016 (a) Northern Maida

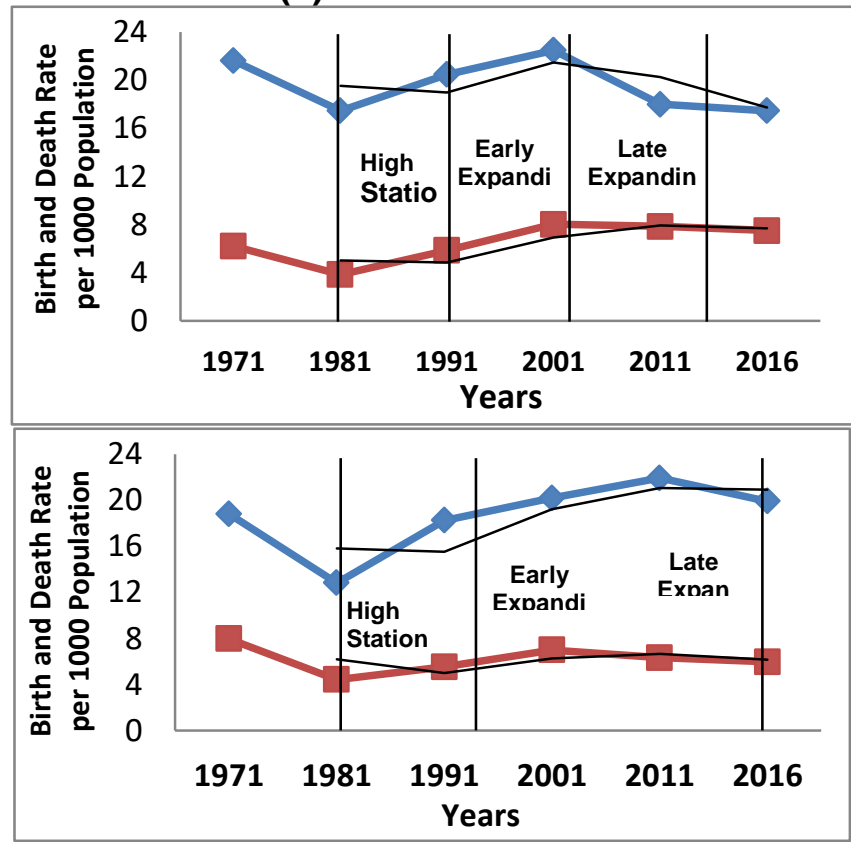

(c) Coastal Region

$$
\begin{aligned}
& - \text { Birth Rate } \\
& -2 \text { per. Mov. Avg. (Birth Rate) }-2 \text { per. Mov. Avg. ([ }
\end{aligned}
$$

(b) Southern Maidan
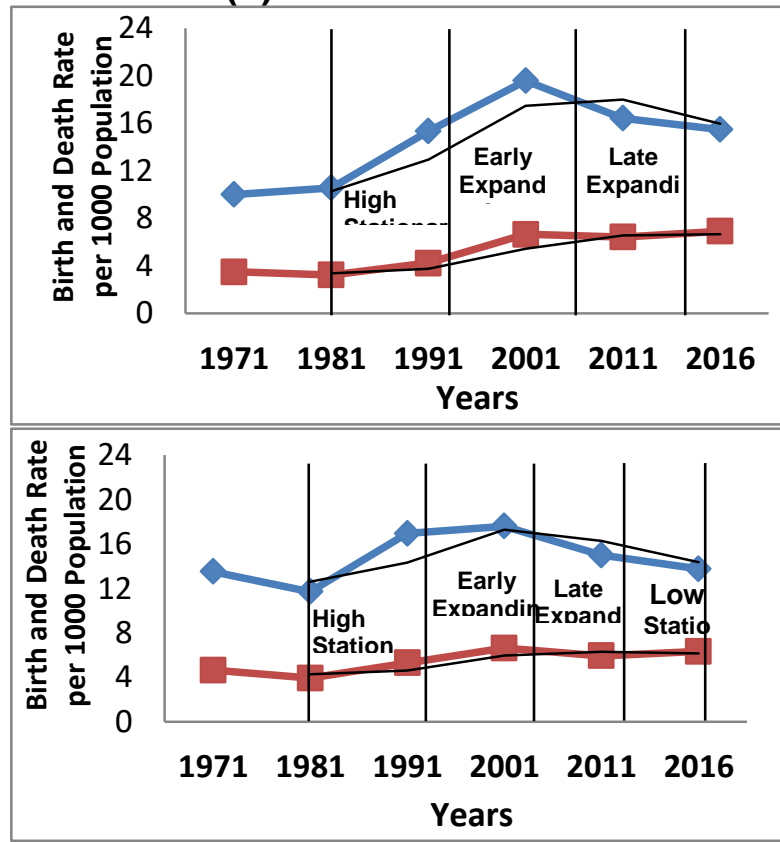

(d) Malnad Region

\section{Key Variables of the Development}

In this study four variables are used to show impact of demographic transition on the development such as Work Participation Rate (WPR), Literacy Rate (LR), Life Expectancy (LE) and Net District Income (NDI) whereas Population Growth Rate (PGR) is used as control variable. Table 2 shows the results of Partial correlation with 2-tailed significance for various physiographic divisions of the state. This can be explained as follows:

\section{Work Participation Rate (WPR)}

The Work Participation Rate (WPR) is defined as the proportion of total workers (i.e. main and marginal workers) to total population (Census of India. 2011). This rate shows almost positive with all other variables in all the physiographic divisions in which Southern Maidan shows appreciable correlation with the Literacy Rate (LR) and Net District Income (NDI) while the Northern Maidan shows less positive correlation between WPR and NDI. In coastal region WPR has less positive correlation with literacy rate due to the rapid increase of literacy rate over four decades while the WPR is gradual increasing over the period of time. Furthermore, Malnad shows average positive correlation with all other variables.

\section{Literacy Rate (LR)}

The percentage of literates to the total population of the region is called as Literacy rate. Northern Maidan shows very high correlation with Life Expectancy (LE) in contrary to this it shows negative correlation value with Net District Income (NDI) of the region. Southern Maidan has strong correlation with WPR and NDI which indicates the socio-economic development of the region. In Malnad and Costal regions, remarkable correlation has found with LE which reflects the health conditions are more linked with the literacy rate.

\section{Life Expectancy (LE)}

Life Expectancy at birth is the key indicator of health. Southern Maidan shows highest positive correlation with NDI whereas Northern Maidan shows negative Correlation with the same variable. A good association also found between LE and WPR in Malnad region where as average relationship are found with all other variable except LR in Coastal Region.

\section{Net District Income (NDI)}

Income of the districts is also estimated in terms of Net District Income (NDI). A significant correlation has been observed with all other variables in Southern Maidan Region whereas 
literacy rate and life expectancy shows negative relationship with NDI in Northern Maidan. Coastal and Malnad region shows least positive correlation with WPR as well as average relationship found with other variables.

\section{Population Growth Rate (PGR)}

Decadal variation in the population is used for the population growth of the region. Here, PGR is taken as a control variable which impacts on the changes in all other variables.

Table 02: Division wise Results of Partial Correlation

(a) Northern Maidan

\begin{tabular}{|c|c|c|c|c|c|c|}
\hline \multicolumn{3}{|c|}{ Control Variables } & WPR & LR & LE & $\mathrm{NDI}$ \\
\hline \multirow[t]{8}{*}{ PGR } & \multirow[t]{2}{*}{ WPR } & Correlation & 1.000 & .952 & .964 & .097 \\
\hline & & $\begin{array}{l}\text { Significance } \\
\text { (2-tailed) }\end{array}$ & & .199 & .170 & .938 \\
\hline & \multirow[t]{2}{*}{ LR } & Correlation & .952 & 1.000 & .999 & -.213 \\
\hline & & $\begin{array}{l}\text { Significance } \\
\text { (2-tailed) }\end{array}$ & .199 & & .028 & .863 \\
\hline & \multirow[t]{2}{*}{ LE } & Correlation & .964 & .999 & 1.000 & -.170 \\
\hline & & $\begin{array}{l}\text { Significance } \\
\text { (2-tailed) }\end{array}$ & .170 & .028 & & .891 \\
\hline & \multirow[t]{2}{*}{ NDI } & Correlation & .097 & -.213 & -.170 & 1.000 \\
\hline & & $\begin{array}{l}\text { Significance } \\
\text { (2-tailed) }\end{array}$ & .938 & .863 & .891 & \\
\hline
\end{tabular}

(c) Coastal Region

\begin{tabular}{|c|c|c|c|c|c|c|}
\hline \multicolumn{3}{|c|}{ Control Variables } & WPR & LR & LE & NDI \\
\hline \multirow[t]{8}{*}{ PGR } & \multirow[t]{2}{*}{ WPR } & Correlation & 1.000 & .705 & .559 & .111 \\
\hline & & $\begin{array}{l}\text { Significance } \\
\text { (2-tailed) }\end{array}$ & & .502 & .622 & .929 \\
\hline & \multirow[t]{2}{*}{ LR } & Correlation & .705 & 1.000 & .982 & .784 \\
\hline & & $\begin{array}{l}\text { Significance } \\
\text { (2-tailed) }\end{array}$ & .502 & & .120 & .427 \\
\hline & \multirow[t]{2}{*}{ LE } & Correlation & .559 & .982 & 1.000 & .886 \\
\hline & & $\begin{array}{l}\text { Significance } \\
\text { (2-tailed) }\end{array}$ & .622 & .120 & & .306 \\
\hline & \multirow[t]{2}{*}{ NDI } & Correlation & .111 & .784 & .886 & 1.000 \\
\hline & & $\begin{array}{l}\text { Significance } \\
\text { (2-tailed) }\end{array}$ & .929 & .427 & .306 & \\
\hline
\end{tabular}

(b) Southern Maidan

\begin{tabular}{|c|c|c|c|c|c|c|}
\hline \multicolumn{3}{|c|}{ Control Variables } & WPR & LR & LE & $\mathrm{NDI}$ \\
\hline \multirow[t]{8}{*}{ PGR } & \multirow[t]{2}{*}{ WPR } & Correlation & 1.000 & .998 & .893 & .963 \\
\hline & & $\begin{array}{l}\text { Significance } \\
\text { (2-tailed) }\end{array}$ & & .040 & .297 & .175 \\
\hline & \multirow[t]{2}{*}{ LR } & Correlation & .998 & 1.000 & .919 & .978 \\
\hline & & $\begin{array}{l}\text { Significance } \\
\text { (2-tailed) }\end{array}$ & .040 & & .257 & .135 \\
\hline & \multirow[t]{2}{*}{ LE } & Correlation & .893 & .919 & 1.000 & .982 \\
\hline & & $\begin{array}{l}\text { Significance } \\
\text { (2-tailed) }\end{array}$ & .297 & .257 & & .122 \\
\hline & \multirow[t]{2}{*}{ NDI } & Correlation & .963 & .978 & .982 & 1.000 \\
\hline & & $\begin{array}{l}\text { Significance } \\
\text { (2-tailed) }\end{array}$ & . 175 & .135 & .122 & \\
\hline
\end{tabular}

(d) Malnad Region

\begin{tabular}{|c|l|l|r|r|r|r|}
\hline \multicolumn{3}{|l|}{ Control Variables } & WPR & \multicolumn{1}{c|}{ LR } & \multicolumn{1}{c|}{ LE } & NDI \\
\hline PGR & WPR & Correlation & 1.000 & .971 & .918 & .186 \\
\cline { 3 - 7 } & $\begin{array}{l}\text { Significance } \\
\text { (2-tailed) }\end{array}$ &. & .153 & .260 & .881 \\
\cline { 2 - 7 } & LR & Correlation & .971 & 1.000 & .986 & .414 \\
\cline { 2 - 7 } & $\begin{array}{l}\text { Significance } \\
\text { (2-tailed) }\end{array}$ & .153 &. & .107 & .728 \\
\cline { 2 - 7 } & LE & Correlation & .918 & .986 & 1.000 & .561 \\
\cline { 2 - 7 } & $\begin{array}{l}\text { Significance } \\
\text { (2-tailed) }\end{array}$ & .260 & .107 &. & .621 \\
\cline { 2 - 7 } & NDI & Correlation & .186 & .414 & .561 & 1.000 \\
\cline { 2 - 7 } & $\begin{array}{l}\text { Significance } \\
\text { (2-tailed) }\end{array}$ & .881 & .728 & .621 & \\
\hline
\end{tabular}

\section{Conclusion}

From foregoing analysis, it was found that Southern Maidan which experiencing 'low stationary' transition stage has high impact on the variables of development in contrary to this Northern Maidan which is still remains in the 'Late Expanding' stage of transition has shown less development. Coastal and Malnad region stands next to the Southern Maidan in terms of development. Although Net District Income shows positive correlation with Work Participation Rate among all the regions, it is not showing effective impact as the economy of the state is not observing working population except Southern Maidan. Finally, the study suggests that the Government have to take policy measures to improve the work rate among the population.

\section{References}

1. Husain, Majid (2011) Human Geography. Rawat Publications.

2. Lakshmana. C. M (2010) Dynamic of Population Change in Karnataka-An Overview. ISEC.

3. Majumdar. P. K (2010) Fundamentals of Demography. Rawat Publications.

4. Menike, H. R. Anulawathie (2014) The Impact of Demographic Transition on the Economic Growth and Development in Sri Lanka from 1963 to 2007. IJ RMBSS Journal, vol.2, Issue.2, June.2014.

5. Ranganatha (2012), Geography of Karnataka. Mysore Book House.

6. Rayappa, P. Hanumantha (1998) Demographic Transition in Karnataka: A Regional Perspective. Journal of Social and Economic Development. Vol.1, No.1, Jan-June 1998, p.p.85-106.

7. Thakur, Vasundhra (2012) The Demographic Dividend in India: Gift or curse? A State level analysis on differing age structure and its implications for India's economic growth prospects. LSE Journal, Working Paper series.2012, No.12-128. 